\title{
ANALISIS YURIDIS PENYELESAIAN SENGKETA PEMILIHAN KEPALA DESA YANG MENDAPAT SUARA SAMA DI DESA MASBAGIK SELATAN KABUPATEN LOMBOK TIMUR
}

\author{
Hulaimi \\ Fakultas Hukum Universitas Gunung Rinjani \\ e-mail : hhulaimi2020@gmail.com
}

\section{Info Artikel}

Sejarah Artikel :

Diterima 22 April 2021

Disetujui 26 April 2021

Publikasi Mei 2021

\section{Keyword:}

Masbagik South Village, East Lombok Regency, Village Head Election

\section{Alustract}

The purpose of this research is to find out how the dispute resolution mechanism of the election results for the Head of South Masbagik Village, East Lombok Regency is based on the Laws and Regulations. Knowing how the legal considerations in Decision Number: 08 / G / 2018 / PTUN.Mtr and PTUN Surabaya Decision Number: 173 / B / 2018 / PT.TUN.SBY are in accordance with statutory regulations in resolving the same vote dispute. This study the authors use the Normative research method, with an approach method using library legal materials in other words, library research. This study the authors used a normative research method, with an approach method using library law materials, in other words, library research. The method of collecting legal materials used is documentation study, namely by recording information from legal materials related to dispute resolution mechanisms based on statutory regulations, as well as those obtained from other sources, either expert opinion, research results or journals.

\section{Ahstrak}

Tujuan dari penelitian ini adalah untuk mengetahui bagaimana mekanisme penyelesaian sengketa hasil pemilihan Kepala Desa Masbagik Selatan Kabupaten Lombok Timur berdasarkan Peraturan Perundang-Undangan. Mengetahui bagaimana pertimbangan hukum dalam Putusan Nomor: 08/G/2018/PTUN.Mtr dan Putusan PTUN Surabaya Nomor: 173/B/2018/PT.TUN.SBY telah sesuai dengan peraturan perundang-undangan dalam penyelesain sengketa suara sama. Penelitian ini penulis gunakan metode penelitian Normatif, dengan metode pendekatan dengan menggunakan bahan hukum pustaka adengan kata lain, penelitian kepustakaan (Library Reaserch). Penelitian ini penulis menggunakan metode penelitian normatif, dengan metode pendekatan dengan menggunakan bahan hukum pustaka adengan kata lain, penelitian kepustakaan (Library Reaserch). Cara pengumpulan bahan hukum yang digunakan adalah studi dokumentasi yakni dengan mencatat informasi dari bahan hukum yang berkaitan dengan mekanisme penyelesaian sengketa berdasarkan peraturan perundang-undangan, maupun yang diperoleh dari sumber lain, baik pendapat ahli, hasil penelitian maupun jurnal. 


\section{A. PENDAhuluan}

Pemilihan Kepala Desa (pilkades) merupakan salah satu ajang pesta demokrasi dari tingkatan terrendah yakni desa. yang bertujuan untuk memilih pemimpin yang berasal dari masyarakat desa, seperti pemilihan lain, dan dalam proses inipun tentu ada yang menang dan adapula yang kalah, akan tetapi tak semua kekalahan itu bisa diterima dengan ikhlas, dengan hati lapang dada dan menjadikan pilkades adalah proses yang biasa dalam setiap pergantian kepemimpinan. Tak sedikit pula peserta atau pendukung yang menerima akan kekalahan dalam pilkades, dengan berbagai sebab atau alasan diantaranya yang paling banyak mengemukan adalah merasa dirugikan dengan hasil yang diperolehnya, ada kecurangan atau bahkan ada politik uang. Ketidakterimaan atas hasil pilkades tersebut harus berujung pada konflik antar pendukung yang tak kunjung selesai, dan bahkan terhadap pihak yang kalah dalam pilkades mengajukan keberatan atau sengketa hasil pilkades sesuai prosedur yang ada menurut peraturan perundang-undangan.

Pelaksanaan pilkades tidak lepas dari peraturan yang telah di buat oleh pemerintah yang kemudian di tetapkan oleh DPR atau DPRD dalam bentuk peraturan perundangundangan baik tingkat pusat maupun daerah. Harus diakui bahwasanya dan telah menjadi pengetahuan umum kalau demokrasi tertua di republik ini ada di desa, karena desa sejak kurang lebih 2 (dua) abad lalu atau massa kolonial sudah menggelar pemilihan untuk menentukan pemimpinnya. Hal ini menjadi ciri perwujudan demokrasi tingkat desa dengan adanya pilkades secara langsung sudah berlangsung sejak lama dan bahkan terpelihara dengan baik, karena dari desa kita mengenal namanya pemilihan pemimpin secara langsung dengan masyarakat dengan memberikan hak suaranya masing-masing.

Beberapa kali perubahan peraturan tentang pilkades di lakukan hingga saat ini, sejak berlakunya Undang-Undang Nomor 6 Tahun 2014 tentang Desa (selanjutnya disingkat UU Desa) ${ }^{1}$, pemerintah mengatur

1 Pemerintah Indonesia, Undang-Undang Nomor 6 Tahun 2014 tentang Desa (Lembaran Negara Republik Indonesia Tahun 2014 Nomor 7, Tambahan Lembaran Negara Republik Indonesia Nomor 5495). pilkades di laksanakan secara bersama-sama atau serentak seperti pemilihan kepala daerah (pilkada), ketentuan ini diatur dalam ketentuan pasal 31 ayat (1) UU Desa. Selanjutnya dalam aturan pelaksanaan UU Desa yaitu dalam ketentuan pasal 40 ayat (1) dan (2) Peraturan Pemerintah (selanjutnya disingkat PP) Nomor 43 Tahun 2014 Tentang Peraturan Pelaksanaan Undang-Undang Nomor 6 Tahun 2014 Tentang Desa², yang menyatakan, ayat (1) "Pemilihan kepala Desa dilaksanakan secara serentak di seluruh wilayah kabupaten/kota", sedangkan ayat (2) menyatakan "Pemilihan kepala Desa secara serentak sebagaimana dimaksud pada ayat (1) dapat dilaksanakan bergelombang paling banyak 3 (tiga) kali dalam jangka waktu 6 (enam) tahun".

Berdasarkan hal tersebut kemudian Menteri Dalam Negeri selaku pelaksana tugas dan fungsi (selanjutnya disingkat tufoksi) yang mengurus pemerintah daerah dan pemerintah desa menerbitkan Peraturan Menteri Dalam Negeri (selanjutnya disingkat Permendagri) Nomor 112 Tahun 2014 Tentang Pemilihan Kepala Desa ${ }^{3}$, sebagaimana dalam pasal 2 menyatakan "Pemilihan Kepala Desa dilakukan secara serentak satu kali atau dapat bergelombang". Selanjutnya dalam pasal 4 ayat (2) menyatakan "Pemilihan Kepala Desa secara bergelombang sebagai mana dimaksud pada ayat (1) dilaksanakan paling banyak 3 (tiga) kali dalam jangka waktu 6 (enam) tahun". Dan ayat (3) menyatakan "Pemilihan Kepala Desa bergelombang sebagaimana dimaksud pada ayat (2) dilakukan dengan interval waktu paling lama 2 (dua) tahun".

Sehingga pelaksanaan pilkades harus dilaksanakan secara serentak di seluruh wilayah kabupaten atau kota, dengan ditetapkan Peraturan Daerah (Perda) Kabupaten Lombok Timur Nomor 4 Tahun 2015 Tentang Tata Cara Pemilihan dan

2 Pemerintah Indonesia, Peraturan pemerintah Nomor 43 Tahun 2014 tentang Peraturan Pelaksana Undang-Undang Nomor 6. Tahun 2014. tentang Desa (Lembaran Negara Republik Indonesia Tahun 2014 Nomor 123, Tambahan Lembaran Negara Republik Indonesia Nomor 5539)

3 Pemerintah Indonesia, Peraturan Menteri Dalam Negeri Nomor 112 Tahun 2014 Tentang Pemilihan Kepala Desa (Berita Negara Republik Indonesia Tahun 2014 Nomor 2092) 


\section{Pemberhentian Kepala Desa, pasal 4} menyatakan ${ }^{4}$ :

(1) Pemilihan kepala Desa secara serentak sebagaimana dimaksud dalam Pasal 3 huruf a dilaksanakan di seluruh wilayah daerah.

(2) Pemilihan Kepala Desa secara serentak sebagaimana dimaksud pada ayat (1) dapat dilaksanakann bergelombang paling banyak 3 (tiga) kali dalam jangka waktu 6 (enam) tahun.

(3) Pemilihan Kepala Desa bergelombang sebagaimana dimaksud pada ayat (2) dilakukan dengan interval waktu paling lama 2 (dua) tahun.

(4) Pemilihan Kepala Desa serentak untuk pertama kali dilaksanakan pada tahun 2016.

(5) Jadwal pelaksanaan pemilihan Kepala Desa serentak ditetapkan oleh Bupati atas usul panitia pemilihan kabupaten.

Pelaksanaan dari Perda No. 4 Tahun 2015, Bupati H. Moch. Ali Bin Dachlan yang menjabat pada saat itu menerbitkan Peraturan Bupati (Perbup) Nomor 15 Tahun 2016 Tentang Peraturan Pelaksana Perda No. 4 Tahun 2015 Tentang Tata Cara Pemilihan dan Pemberhentian Kepala Desa, yang secara teknis dalam Perbup tersebut memperjalas tahun pelaksanaan pilkades di Kabupaten Lombok Timur sebagaimana pasal $3^{5}$ yaitu pada tahun 2016, 2017 dan 2020.

Salah satu prinsip dasar pengaturan pilkades adalah demokrasi secara langsung, umum, bebas dan rahasia, yang selama ini akrab di kenal dengan sebutan LUBER, sebagaimana prinsip Pemilihan Umum (Pemilu) sejak tahun $1971 .^{6}$ Pelaksanaan

4 Pemerintah Indonesia, Peraturan Daerah Kabupaten Lombok Timur Nomor 4 Tahun 2015 Tentang Tata Cara Pemilihan dan Pemberhentian Kepala Desa (Lembaran Daerah Kabuapten Lombok Timur Tahun 2015 Nomor 4, Tambahan Lembaran Daerah Kabuapten Lombok Timur Nomor 3)

5 Pemerintah Indonesia, Peraturan Bupati Nomor 15 Tahun 2016 Tentang Peraturan Pelaksana Perda No. 4 Tahun 2015 Tentang Tata Cara Pemilihan dan Pemberhentian Kepala Desa (Berita Daerah Kabupaten Lombok Timur Tahun 2016, Nomor 16).

${ }^{6}$ Basri Mulyani dan Zainul Fikri, Perilaku Memilih : Analisis Terhadap Tingginya. Surat suara Tidak Sah (Studi Kasus Kota Mataram), Laporan Hasil Penelitian, pilkades harus benar-benar mengahasilkan pemimpin yang demokratis secara subtantif dan prosedural. Sehingga demi terlaksananya hal tersebut penting tersedianya aturan main yang jelas dan konsisten dalam pelaksanaan pilkades termasuk mekanisme penyelesaian sengketa yang pasti akan terjadi. Karena catatan bersama konflik yang kerap terjadi di Indonesia sebagian karena proses pemilihan, baik kepala daerah maupun kepala desa. Selalu diawali dari proses ketidakpuasan salah satu calon yang kalah dalam pemilihan?.

Apabila proses pilkades yang berlangsung dan telah selesai di lakukan maka tahapan perhitungan suara menjadi pokok dari pemilihan tersebut dilaksanakan, hingga pada proses pengangkatan Kepala Desa Terpilih. Pada sisilain, jika terjadi sengketa hasil perhitungan suara Pilkades di perlukan sebuah lembaga penyelesain yang adil dan transparan dalam pelaksanaannya. Lembaga mana benar-benar harus memahami hukum pemilihan umum dan proses penyelesain sengketa menurut peraturan perundang-undangan agar keputusan yang dihasilkan benar-benar sesuai dengan rasa keadilan masyarakat yang mencari pemimpin.

Pasal 37 ayat (6) UU Desa, cukup jelas mengatur dalam hal terjadi perselisihan hasil pemilihan Kepala Desa, Bupati/Walikota wajib menyelesaikan perselisihan dalam jangka waktu 30 (tiga puluh) hari, sejak tanggal di terimanya penyampain hasil pemilihan dari Panitia Pemilihan Kepala Desa. ${ }^{8}$

Namun, ketentuan tersebut tidak di atur secara jelas dan rinci bagaimana mekanisme pembentukanya dan kekuatan keputusan hasil penyelesaian sengketanya. Karena tidak jelasnya pengaturan dan tidak tepatnya lembaga yang berwenang dalam menyelesain perselisihan hasil Pilkades dapat menimbulkan berbagai permasalahan, karena tidak obyektifnya lembaga yang berwenang yang menyelesaikan hasil pemilihan tersebut. Apalagi turut campurnya Bupati sangat tidak sesuai dengan asas otonomi asli yang dimiliki

http:/,repository.gac,id:1015/id/eperint/18, (diakses tanggal 9 Maret 2020)

7 Ibid

8 Pasal 37 Ayat (6) Undang-Undang Nomor 6 Tahun 2014 tentang Desa (Lembaran NegaraTahun 2014 Nomor 7,Tambahan Lembaran Negara Nomor 5495) 
desa. Karena sengketa pilkades dapat terjadi antar peserta dengan penyelenggara maupun antara peserta dengan peserta bahkan dapat dikatakan semua orang memiliki potensi untuk dapat terlibat dalam sengketa Pilkades.

Berkaitan dengan mekanisme penyelelesain sengketa Kepala Desa, dalam ketentuan Pasal 42 Perda Kabupaten Lombok Timur Nomor 4 Tahun 2015 Tentang Tata Cara Pemilihan dan Pemberhentian Kepala Desa menjelaskan bahwa:

1) Keberatan terhadap penetapan hasil pemilihan Kepala Desa hanya dapat di ajukan oleh Calon Kepala Desa kepada Bupati dalam Waktu paling lambat 3 (Tiga) hari kerja setelah penetapan hasil pemilihan;

2) Keberatan di maksud pada ayat (1), hanya berkenaan dengan Hasil perhitungan suara yang mempengaruhi terpilinnya Calon Kepala Desa;

3) Bupati memutus sengketa hasil penghitungan suara sebagaimana yang di maksud pada ayat (1) dan ayat (2), dengan memberikan usulan/masukan kepada panitia penyelenggara pemilihan kepala Desa, ke BPD, Camat dan Tim yang di bentuk oleh bupati.

4) Penyelesain hasil peerselisihan hasil perhitungan suara di laksanakan dalam jangka waktu paling lama 30 (tiga puluh) hari sebagaimana di maksud dalam Pasal 41 ayat (5); dan

5) Keputusan Bupati sebagaimana yang di maksud pada ayat (3) bersifat final dan mengikat.

Perda Kabupaten Lombok Timur Nomor 4 Tahun 2015 Tentang Tata Cara Pemilihan dan Pemberhentian Kepala Desa telah mengamanatkan peraturan mengenai mekanisme penyelesain sengketa Pilkades dalam Peraturan Bupati, dengan bentuk sengketa yang bermacam-macam, mekanisme penyelesain sengketa yang diatur dalam Perda harus juga mengatur ketentuan mengenai penyelesain sengketa dalam pelaksanaan pemilihan kepala desa, dimana secara umum juga mengatur penyelesain sengketa secara pidana.

Berdasarkan Peraturan Daerah Kabupaten Lombok Timur Nomor 4 Tahun
2015, gelombang pertama pemilihan kepala desa serentak di wilayah Kabupaten Lombok Timur pada tanggal 14 Desember 2016 telah dilaksanakan di 53 (lima puluh tiga) desa yang tersebar di 19 (sembilan belas) kecamatan dari 20 (dua puluh) jumlah kecamatan yang ada di Kabupaten Lombok Timur. Tercatat hanya 1 (satu) kecamatan yakni Kecamatan Sambelia yang di wilayahnya tidak ada pemilihan kepala desa. ${ }^{9}$

Jumlah keseluruhan calon kepala desa yang mengikuti pemilihan kepala desa serentak di 53 (lima puluh tiga) desa di Kabupaten Lombok Timur sebanyak 202 (dua ratus dua) orang. 20 (dua puluh) desa diantaranya memiliki calon kepala desa sebanyak 5 (lima) orang, 8 (delapan) desa lainnya memiliki 4 (empat) orang calon kepala desa. Sementara jumlah desa yang memiliki calon kepala desa sebanyak 3 (tiga) orang juga berjumlah 20 (dua puluh) desa dan hanya 5 (lima) desa saja yang memiliki calon kepala desa sebanyak 2 (dua) orang. ${ }^{10}$

Pelaksanaan pemilihan kepala Desa serentak bedasarkan peraturan Daerah Kabupaten Lombok Timur Nomor 4. Tahun 2015, tentang cara pemilihan kepala desa dan pemberhentian kepala desa selama tahap pertama pemilihan kepala desa serantak yang di laksanakan pada tanggal 14 Desember 2016 tersebut tidak semua berjalan dengan baik dan mulus, tercata ada 3 (tiga) desa yang mengalami sengketa dalam pelaksanaan pemilihan kepala desa yaitu desa Dasan Borok kecamtan Suralaga, desa Tanjung Luar kecamatan Keruak dan desa Batu Nampar kecamatan Jerowaru. Pihak-pihak yang terlibat dalam sengketa pemilihan pilkades tersebut adalah peserta pemilihan kepala desa serentak dan panitia penyelenggara pemilihan kepala desa serentak.

Sedangkan pilkades serentak tahap kedua tanggal tanggal 13 Desember 2017 terdapat 7 (tujuh) sengketa diantaranya Desa Toya, Temanjor, Desa Padak Guar, Desa Jerowaru dan salah satunya Desa Masbagik

${ }^{9}$ BPMPD Kab. Lotim, "Rekapitulasi Data Pemilihan Kepala Desa Serentak" di Kab. Lombok Timur Tahun 2016

${ }^{10}$ Sima Rista, Demokrasi Akar Rumput Damai, Kompetitif, Mendidik, Majalah Gempita Gumi Selaparang, Edisi Oktober 2016 
Selatan. ${ }^{11}$ Dimana satu-satunya Pilkades yang calonya memperoleh suara sama, pilkades Masbagik Selatan yang di yang di ikuti Oleh 5 (lima) Calon Kepala Desa, terdapat 2 (dua) Calon Kepala Desa memperoleh suara paling banyak dan jumlahnya adalah sama setelah hasil rekapitulasi perhitungan di tingkat Desa. Panitia Pemilihan Kepala Desa Masbagik Selatan menetapkan masing-masing perolehan suara Calon Kapala Desa Masbagik Selatan adalah sebagai berikut:

Tabel 1 : Rekapitulasi Hasil Perhitungan Suara Pilkades Masbagik Selatan

\begin{tabular}{|c|c|c|}
\hline $\begin{array}{c}\text { NO } \\
\text { URUT }\end{array}$ & NAMA CALON & $\begin{array}{c}\text { PEROLEHAN } \\
\text { SUARA }\end{array}$ \\
\hline 1 & $\begin{array}{c}\text { KURDIANSAH. } \\
\text { Amd, Kep }\end{array}$ & 551 \\
\hline 2 & HUSNADI PRATAMA & 1573 \\
\hline 3 & JANRISWADI & 1097 \\
\hline $\mathbf{4}$ & H.WIRIYAWAN.SH & $\mathbf{2 4 4 1}$ \\
\hline $\mathbf{5}$ & MASDAR & $\mathbf{2 4 4 1}$ \\
\hline
\end{tabular}

Sumber : Keputusan Panitia Pemilihan Kepala Desa Masbagik Selatan

Hasil pemilihan dimana 2 (dua) calon memperoleh suara sama yakni Calon Kades Masdar dan Calon Kades H. Hirawan, SH., MH yang sama-sama memperoleh suara 2441 (Dua Ribu Empat Ratus Empa Puluh Satu), oleh Panitia Pilkades Masbgik Selatan, menetapkan H. Hirawan SH.,MH. sebagai Calon Kepala Desa Masbagik Selatan, tetapi Calon Kepala Desa Masdar keberatan atas penetapan H. Hirawan, SH.,MH, sebagai calon terpilih dan mengajukan keberatan ke Panitia Pemilihan Kepala Desa tingkat Kabupaten Lombok Timur melalui Panitia Pemilihan Kepala Desa Masbagik Selatan, tidak hanya sampai disana gugatan sengketa administrasi juga di ajukan ke pengadilan Tata Usaha Negara Mataram oleh Masdar.

Berdasarkan uaraian di atas, penulis tertarik untuk melakukan penelitian mengenai hal tersebut, untuk di jadikan kajian dalam penelitian ini dengan rumusan masalah sebagai berikut: Pertama, Bagaimana mekanisme penyelesaian sengketa hasil pemilihan kepala desa di Kabupaten Lombok Timur berdasarkan peraturan perundangundangan?. Kedua, Bagaimanakah dasar

11 https://radarlombok.co.id/giliran-masbagikselatan-tolak-hasil-pilkades.html (10 Mei 2020) pertimbangan hukum Hakim PTUN Mataram Nomor 08/G/2018/PTUN.Mtr dan Putusan PT.TUN Surabaya Nomor 173/B/2018/PT.TUN.SBY dalam menjatuhkan putusan sengketa administrasi Pilkades dalam suara sama dan apakah telah sesuai dengan peraturan perundang-undangan dalam penyelesain sengketa suara sama.

\section{B. METODELOGI PENELITIAN}

Penelitian ini menggunakan metode penelitian Normatif, dengan metode pendekatan dengan menggunakan bahan hukum pustaka adengan kata lain, penelitian kepustakaan (Library Reaserch). Study ini dilakukan dengan cara mengumpulkan bahan hukum sekunder, premier dan bahan hukum tersier, dengan membaca, serta meneliti buku-buku, makalah berbagai tulisan yang berhubungan langsung dengan judul serta putusan hakim PTUN atas putusan hasil Pemilihan Kepala Desa Masbagik Selatan yang memperoleh suara sama. Permasalahan penelitian tersebut adalah analisa yuridis pertimbangan hakim PTUN atas putusan hasil Pemilihan Kepala Desa Masbagik Selatan yang memperoleh suara sama.

Penelitian ini menggunakan metode pendekatan: pertama, pendekatan perundang-undangan (statute approach) dilakukan dengan menelaah semua undangundang dan regulasi yang berkaitan dengan masalah yang dibahas. Kedua, pendekatan konseptual (conseptual approach), mengkaji pandangan/konsep para ahli yang berkenaan dengan masalah yang dibahas. Dan ketiga, pendekatan kasus (case approach), pendekatan yang dilakukan dengan cara melakukan telaah terhadap kasus-kasus yang berkaitan dengan isu yang dihadapi yang telah menjadi putusan pengadilan yang telah mempunyai kekuatan hukum yang tetap. ${ }^{12}$

Jenis bahan hukum dapat dibedakan menjadi 3, yaitu: bahan hukum primer, bahan hukum sekunder, bahan hukum tertier. Dalam penelitian ini, penulis menggunakan sumber bahan hukum yaitu: pertama, sumber bahan hukum primer yang

${ }^{12}$ Peter Mahmud Marzuki, Penelitian Hukum, Cet II (Kencana Prenada Media Group : Jakarta, 2006), hal 24 
digunakan terdiri dari peraturan perundangundangan, catatan resmi, risalah dalam pembuatan perundang-undangan dan putusan hakim. ${ }^{13}$ Kedua, bahan hukum sekunder yang utama adalah buku teks karena buku teks berisi mengenai prinsipprinsip dasar ilmu hukum dan pandanganpandangan klasik. Ketiga, sumber bahan hukum tertier adalah bahan yang memberikan petunjuk maupun penjelasan terhadap bahan hukum primer dan sekunder.

Cara atau teknis pengumpulan bahan hukum yang digunakan adalah studi dokumentasi yakni dengan mencatat informasi dari bahan hukum yang berkaitan dengan mekanisme penyelesaian sengketa berdasarkan peraturan perundang-undangan, baik secara normatif maupun berupa ide atau gagasan. Pencatatan dilakukan secara selektif untuk mendukung dan melengkapi bahan hukum yang diperoleh dari sumber lain, baik pendapat ahli, hasil penelitian maupun jurnal.

Seluruh bahan hukum yang diperoleh dari penelitian kepustakaan selanjutnya akan dianalisis secara deskriptif-kualitatif dengan membangun argumen berdasarkan logika berfikir deduktif. Dengan metode deskriptifkualitatif, peneliti akan menyajikan dan menguraikan serta menghubungankan tiga dari analisis tersebut seluruh bahan hukum yang relevan yang telah diperoleh dari penelitian kepustkaan secara sistematis komprehensif dan akurat. Bersamaan dengan itu, penulis juga melakukan penafsiran terhadap bahan hukum. Sehingga diperoleh jawaban atas permasalahan secara akurat dan komprehensif. ${ }^{14}$

\section{PEMBAHASAN}

\section{1) Penyelesaian Sengketa Pemilihan Kepala Desa Oleh Pemerintah Daerah Kabupaten Lombok Timur dan Pengadilan Tata Usaha Negara}

Pengertian Pilkades baru ditemukan dalam Peraturan Menteri Dalam Negeri Nomor 112 Tahun 2014 (Permendagri No. 112 Tahun 2014) tentang Pemilihan Kepala Desa sebagai tindak lanjut dari Peraturan Pemerintah Nomor 43 Tahun 2014,

\footnotetext{
${ }^{13}$ Ibid., hal 141

14 Nasition,S.,Metode Penelitian Kualitatip,(Tarsito : Bandung,1992), Hal.126
}

dirumuskan bahwa pemilihan kepala desa adalah "pelaksanaan kedaulatan rakyat di desa dalam rangka memilih kepala desa yang bersifat langsung, umum, bebas, rahasia, jujur, dan adil". ${ }^{15}$

Jika dicermati pengertian pemilihan kepala desa secara yuridis, linier dengan pengertian pemilihan kepala daerah (gubernur, bupati/walikota), bahkan pemilihan umum pada umumnya untuk memilih anggota DPR, anggota DPD, Presiden dan Wakil Presiden, dan anggota DPRD, yaitu mengandung 3 (tiga) unsur: pertama, sebagai sarana atau pelaksanaan kedaulatan rakyat; kedua, jabatan yang hendak diisi (kepala desa, kepala daerah, Presiden dan Wakil Presiden, serta anggota DPR, DPD, dan DPRD); dan ketiga, prinsip yang menjadi dasar pelaksanaan: LUBER dan Jurdil (langsung, umum, bebas, rahasia, jujur, dan adil). ${ }^{16}$

Dalam Undang-Undang Nomor 6 Tahun 2014, Pasal 37 ayat (6) hanya menentukan "dalam hal terjadi perselisihan hasil pemilihan Kepala Desa, Bupati/Walikota wajib menyelesaikan perselisihan dalam jangka waktu sebagaimana dimaksud pada ayat (5)", sementara pada ayat (5) Pasal 37 tersebut menentukan waktu paling lama 30 (tiga puluh) hari sejak tanggal diterimanya penyampaian hasil pemilihan dari panitia pemilihan Kepala Desa. Jadi Pasal 37 ayat (5) dan ayat (6) Undang-Undang Nomor 6 Tahun 2014 hanya menentukan siapa yang berwenang, yaitu Bupati/Walikota dan jangka waktu yang dialokasikan, yaitu 30 (tiga puluh) hari untuk menyelesaikan perselisihan hasil Pilkades, sedangkan bagaimana tata cara, prosedur, dan mekanismenya yang berkaitan dengan penyelesaiannya hasil pemilihan kepada desa tidak diatur sama sekali. ${ }^{17}$

Begitu pula Peraturan Pemerintah Nomor 43 Tahun 2014 Junto Peraturan Pemerintah

15 Pasal 1 ayat (5) Peraturan Menteri Dalam Negeri Nomor 112 Tahun 2014 Tentang Pemilihan Kepala Desa (Berita Negara Republik Indonesia Tahun 2014 Nomor 2092)

16 Supriyadi, Kajian Yuridis Penyelesaian Perselisihan Hasil Pemilihan Kepala Desa, Jurnal Cakrawala Hukum, DOI: https://doi.org/10.26905/idjch.v10i2.3541.

17 Ibid 
Nomor 47 Tahun 2015 sebagai tindak lanjut dari Undang-Undnag Nomor 6 Tahun 2014 juga tidak mengatur masalah penyelesaian perselisihan hasil Pilkades. Dalam Peraturan Pemerintah ini hanya ada 7 (tujuh) pasal, yaitu: Pasal 40 sampai dengan Pasal 46 yang mengatur malasah tata cara pemilihan kepala desa dan hanya 1 (satu) ayat, yaitu ayat (7) dalam Pasal 41 yang normanya sama dengan Pasal 37 ayat (6) Undang-Undnag Nomor 6 Tahun 2014, yaitu: "dalam hal terjadi perselisihan hasil pemilihan kepala Desa, bupati/walikota wajib menyelesaikan perselisihan dalam jangka waktu 30 (tiga puluh) hari".18

Sebagai tindak lanjut dari Peraturan Pemerintah Nomor 43 Tahun 2014, Menteri Dalam Negeri mengeluarkan Permendagri Nomor 112 Tahun 2014 yang diubah dengan Permendagri Nomor 65 Tahun 201. ${ }^{19}$ Permendagri ini dikeluarkan khusus untuk mengatur masalah pemilihan kepala desa, tetapi sangat disayangkan dari 50 (lima puluh) pasal yang terdapat dalam Peraturan Menteri Dalam Negeri ini justru tidak disinggung sedikit pun tentang persoalan penyelesaian perselisihan hasil Pilkades, apalagi solusi terhadap pelanggaran proses pelaksanaan Pilkades. Kalau pun ada ketentuan yang menyinggung persoalan penyelesaian yang terkait dengan pelaksanaan pemilihan kepala desa secara garis besar, itu pun sangat sumir seperti yang diatur dalam Pasal 5 ayat (2) huruf $f$ Permendagri No. 112 Tahun 2014 sebagai salah satu tugas Panitia Pilkades tingkat kabupaten/kota yang menentukan bahwa "panitia pemilihan di Kabupaten/ Kota mempunyai tugas diantaranya adalah memfasilitasi penyelesaian permasalahan pemilihan kepala desa tingkat kabupaten/kota". Tentu, ketentuan tersebut masih sangat kabur apa yang dimaksud dengan "memfasilitasi penyelesaian permasalahan pemilihan kepala desa tingkat kabupaten/kota". 20

Pemilihan Kepala Desa secara serentak yang dilaksanakan pemerintah daerah

\section{Ibid}

19 Peraturan Menteri Dalam Negrri Nomor 65 Tahun 2017 Tentang Perubahan Peraturan Menteri Dalam Negrri Nomor 112 Tahun 2014 Tentang Pemilihan Kepala Desa

${ }^{20} \mathrm{Ibid}$
Kabupaten Lombok Timur sesuai amanat yang terkandung dalam Undang-Undang Nomor 6 Tahun 2014 Tentang Desa, maka selanjutnya dituangkanlah dalam bentuk Peraturan Daerah yang menjadi landasan hukum pelaksanaan Pemilihan Kepala Desa Secara Serentak di Kabupaten Lombok Timur yakni, Peraturan Daerah Kabupaten Lombok Timur Nomor 4 Tahun 2015 Tentang Tata Cara Pemilihan dan Pemberhentian Kepala Desa, sebagai peraturan pelaksanaan dari perda tersebut maka diatur lagi dalam bentuk Peraturan Bupati yakni Peraturan Bupati Lombok Timur Nomor 15 Tahun 2016 Tentang Peraturan Pelaksanaan Peraturan Daerah Kabupaten Lombok Timur Nomor 4 Tahun 2015 Tentang Tata Cara Pemilihan dan pemberhentian Kepala Desa.

Berdasarkan Undang-Undang Nomor 6 Tahun 2014 Tentang Desa, kewenangan untuk melakukan pelantikan yakni berada ditangan Bupati. Hal ini ditegaskan dalam Pasal 37 UU Desa tersebut telah disebutkan bahwa: (1) Calon Kepala Desa yang dinyatakan terpilih adalah calon yang memperoleh suara terbanyak; (2) Panitia pemilihan Kepala Desa menetapkan calon Kepala Desa terpilih; (3) Panitia pemilihan Kepala Desa menyampaikan nama calon Kepala Desa terpilih kepada Badan Permusyawaratan Desa paling lama 7 (tujuh) hari setelah penetapan calon Kepala Desa terpilih sebagaimana dimaksud pada ayat (2); (4) Badan Permusyawaratan Desa paling lama 7 (tujuh) hari setelah menerima laporan panitia pemilihan menyampaikan nama calon Kepala Desa terpilih kepada Bupati/Walikota; (5) Bupati/Walikota mengesahkan calon Kepala Desa terpilih sebagaimana dimaksud pada ayat (3) menjadi Kepala Desa paling lama 30 (tiga puluh) hari sejak tanggal diterimanya penyampaian hasil pemilihan dari Panitia pemilihan Kepala Desa dalam bentuk keputusan Bupati/ Walikota; (6) Dalam hal terjadi perselisihan hasil pemilihan Kepala Desa, Bupati/ Walikota wajib menyelesaikan perselisihan dalam jangka waktu sebagaimana dimaksud pada ayat (5). Selanjutnya kewenangan bupati untuk melakukan pelantikan disebutkan dalam Pasal 38 Ayat (1) disebutkan: Calon Kepala Desa terpilih dilantik oleh Bupati/Walikota atau pejabat yang ditunjuk paling lama 30 (tiga 
puluh) hari setelah penerbitan keputusan Bupati/Walikota.

Pada tanggal 13 Desember 2017, di desa Masbagik Selatan telah dilaksanakan Pilkades bersamaan dengan desa-desa lainnya yang dilakukan secara serentak di Kabupaten Lombok Timur untuk memilih Kepala Desa yang akan menjabat periode 2017 s/d 2023. Dalam pemilihan tersebut ada salah satu calon yang ikut pilkades di Desa Masbagik Selatan, terdaftar dengan Nomor Urut 5 atas nama Masdar, mengajukan keberatan kepada Panitia Pemilihan Desa selaku pelaksana dari pilkades di Desa Masbagik Selatan. Keberatan yang diajukan oleh Masdar atas Keputusan Panitia Pemilihan Kepala Desa Masbagik selatan yang menetapakan salah satu calon terpilih dari Nomor Urut 4 atas Nama H.Wiryawan, yang dimana panitia pemilihan calon kepala desa terpilih, menetapakan berdasarkan wilayah, dan sebaran TPS yang lebih banyak, berkenaan dengan Keputusan panitia pemilihan kepala desa di Desa Masbagik Selatan, yang telah menetapakan calon kepala desa terpilih degan perolehan suara terbanyak berdasarkan wilayah dan seberan TPS menimbulkan kontra interprestasi.

Dan Pada waktu penghitungan/dan pengumuman suara oleh ketua Panitia Pemilihan Kepala Desa, dengan disaksikan dari berbagai pihak keamanan (Polri, TNI, dan Pol PP) ataupun Ormas/pendukung dari masing-masing pihak, khalayak ramai dan para saksi, yang mana hasil tersebut telah dinyatakan final oleh Panitia Pemilihan Kepala Desa. Dari nomor urut 5 atas nama calon kepala desa Masdar dinyatakan menang. Berselang waktu kemudian, Panitia kembali mengumumkan calon Nomor Urut 5 dan 4 dinyatakan memilih suara sama (draw) dengan Perolehan Suara 2.441 (dua ribu empat ratus empat puluh satu ribu) suara. Sehingga apa yang terjadi pendukung dari nomor urut 5 merasa keberatan atas tindakan yang dilakukan Panitia Kepala Desa, pada saat pengumuman hasil perolehan suara pertama, dengan menyatakan bahwa No Urut 5 mendapatkan suara terbanyak.

Pada tanggal 14 Desember 2017 satu hari setelah Pemilihan Kepala Desa Masbagik Selatan, calon nomor urut 5 (lima) Masdar mengajukan surat kepada Bupati Lombok Timur perihal permohonan perhitungan suara ulang, akan tetapi surat tanggapan tersebut baru ditanggapi dan mendapat jawaban tanggal 17 Januari 2018 dari Pemerintah Kabupaten Lombok Timur melalui Dinas Pemberdayan Masyarakat dan Desa (DPMD), saat proses sengketa dilakukan Panitia Pemilihan Kepala Desa Masbagik Selatan tetap melakukan rapat pleno pada tanggal 15 Desember 2017 dan menerbitkan Berita Acara Pleno Penetapan Calon Kepala Desa Terpilih Periode 2017-2013 dengan surat Nomor: 0023/PPKD-MASSEL/XII/2017, selanjutnya mengeluarkan surat keputusan Panitia Pemilihan Kepala Desa, tentang penetapan calon Kepala Desa Terpilih Nomor 023/PPKD-MASSEL//XII/2017, Tanggal 15 Desember 2017, Periode 2017 s/d 2023.

Penentuan calon terpilih jika ada diantara calon kepala desa yang memiliki suara sama sesbagaimana ketentuan Perda Kabupaten Lombok Timur Nomor 4 Tahun $2015^{21}$ yaini "Dalam hal Calon Kepala Desa yang memperoleh suara terbanyak yang sama, penetapan Calon Kepala Desa Terpilih berdasarkan wilayah perolehan suara yang lebih luas yang diperhitungkan berdasarkan jumlah perolehan suara terbanyak dan sebaran TPS yang lebih banyak. Jika masih diperoleh suara terbanyak dan sebaran TPS yang sama, penetapan calon kepala desa terpilih ditetapkan berdasarkan suara terbanyak pada TPS dengan jumlah pemilih terbanyak".

Peraturan pelaksana yang mengatur Perda Nomor 4 Tahun 2015 yakni dalam ketentuan pasal 56 Peraturan Bupati Lombok Timur Nomor 15 Tahun 2016 Tentang Pelaksanaan Peraturan Daerah Nomor 4 Tahun 2015 Tentang Tata Cara Pemilihan dan Pemberhentian Kepala Desa mengatur hal yang sama dalam penentuan calon terpilih dengan suara yang sama tidak menguraikan secara teknis dan rinci seperti apa seharusnya penentuan calon suara sama tersebut dilakukan. Bahkan dalam panitia pemilihan tingkat kabupaten tidak ada aturan yang mengatur hal suara sama tersebut, sehingga menimbulkan interperstasi yang berbeda-beda dari calon kepala desa.

21 Pasal 40 Tentang Tata Cara Pemilihan dan Pemberhentian Kepala Desa (Lembaran Daerah Tahun 2015 Nomor 70, Tambahan Lembaran Daerah Nomor 3) 
Keberatan yang diajukan oleh calon kepala desa Masdar pada hari berikutnya, semestinya ditunda penetapan calon terpilih yang dilakukan tanggal 15 Desember 2017, karena berdasarkan ketentuan pasal 42 Perda Nomor 4 Tahun 2015 Jounto Pasal 58 Perbup Nomor 15 Tahun 2016 hanya mengatur halhal keberatan sebagai berikut :

(1) Keberatan terhadap penetapan hasil pemilihan kepala desa hanya dapat diajukan oleh Calon Kepala Desa kepada Bupati dalam waktu paling lambat 3 (tiga) hari setelah penetapan hasil pemilihan.

(2) Keberatan sebagaimana dimaksud pada ayat (1), hanya berkenaan dengan hasil penghitungan suara yang mempengaruhi terpilihnya Calon Kepala Desa.

(3) Bupati memutus sengketa hasil penghitungan suara sebagaimana dimaksud pada ayat (1) dan ayat (2), dengan memperhatikan masukan dari panitia pemilihan kepala desa, BPD, Camat, dan tim yang dibentuk oleh Bupati.

(4) Penyelesaian perselisihan hasil penghitungan suara dilaksanakan dalam jangka waktu paling lama 30 (tigapuluh) hari sebagaimana dimaksud dalam Pasal 41 ayat (5).

(5) Keputusan Bupati sebagaimana dimaksud pada ayat (3) bersifat final dan mengikat.

Dari pengaturan tersebut tidak jelas mekanisme penyelesaian sengketa yang diatur dari Perda Nomor 4 Tahun 2015 Jounto Perbup Nomor 15 Tahun 2016. Sehingga interprestasi atas aturan tersebut menimbulkan sengketa lebih lanjut ke Pengadilan Tata Usaha Negara Mataram, Masdar selaku calon kepala desa yang merasa dirugikan dari sisi aturan secara administratif menyatakan Bupati Lombok Timur telah melanggar Asas-asas Umum Pemerintahan yang baik. Adapun Aasa-asas Umum Pemerintahan yang baik (AUPB) yang di langar sebagaimana dalam dalil gugatannya adalah; ${ }^{22}$

a. Azas Kepastian Hukum, yang dimaksud Azas kepastian hukum

22 Putusan Majelis Hakim PTUN Mataran Nomor : 08/G/2018/PTUN Mtr adalah azas mengutamakan peraturan perundang-undangan, kepastian hukum dan keadilan, dalam setiap kebijakan penyelenggara negara. Azas kepastian hukum sudah Menjadi kaidah hukum sebagaimana di maksud dalam pasal 8. 9, dan 10. Undang-Undang Nomor 30 Tahun 2014, tentang Administarasi Pemerintahan, dengan adanya azas ini suatu keputusan haruslah dirumuskan secara jelas dan tegas, agar keputusan yang sampaikan tidak menimbulkan berbagai penafsiran. Sehingga keputusan yang di keluarkan tersebut tidak merugikan penggugat sebagai salah satu calon Kepala Desa Masbagik Selatan.

b. Asas Keadilan dan Kewajaran, yang dimaksud azas ini adalah willekeeureg atau oredelijk menyatakan terlarangnya suatu tindakan, yang apabila badan pemerintahan bertentangan denagan azas-azas ini, maka tindakan itu tersebut dapat di batalkan. Sehingga perbuatan Panitia Pemilihan Desa Masbagik Selatan yang telah mengeluarkan Surat Keputusan Tentang Penetapan Calon Kepala Desa Periode 2017 s/d 2023 tidak di pertimbangkan dengan matang tanpa menunggu jawaban keberatan yang di ajukan oleh Penggugat Kepada Bupati Kabupaten Lombok Timur.

c. Asas Kepentingan Umum, dimaksud dengan azas kepentingan umum (AUPB) adalah azas yang mendahulukan kesejahteraan umum dengan cara asfiratif, akomodatif dan selektif. Dalam hal ini Panitia Pemilihan Desa Masbagik Selatan secara sepihak, dengan telah menerbitkan surat keputusan Panitia Pemilihan Kepala Desa Masbagik Selatan, tentang Penetapan Calon Kepala Desa Terpilih Desa Masbagik Selatan periode 2017 s/d 2023 yang obyek dalam sengketa perkara ini tidak menjelaskan alasan 
menerbitkan surat keputusan tersebut.

Masdar dalam gugatannya di Pengadilan Tata Usaha Negara Mataram memohon kepada majelis hakim yang memeriksa, mengadili dan memutus perkara yang diajukannya untuk menyatakan batal atau tidak sah surat Keputusan Panitia Pemilihan Kepala Desa, Calon Kepala Desa Terpilih Nomor 023/PPKD-MASSEL//XII/2017, Tanggal 15 Desember 2017 tentang Penetapan Calon Kepala Desa terpilih Periode 2017 s/d 2023 dan mewajibkan kepada pihak Panitia untuk mencabut Surat Keputusan tentang penetapan Calaon Kepala Desa Terpilih Nomor 023/PPKD-MASSEL//XII/2017, tanggal 15 Desember 2017 tentang penetapan calon kepala Desa terpilih Masbagik Selatan, Periode 2017 s/d 2023 dan mengeluarkan keputusan Tata Usaha Negara yang baru atas Nama Masdar.

Panitia Pemilihan Kepala Desa Masbagaik Selatan dalam persidangan di Pengadilan Tata Usaha Negara Mataram selaku Tergugat menolak dalil-dalil yang disampaikan oleh Masdar selaku Penggugat dalam perkara yang didaftarkan dengan Register Perkara Nomor 08/G/2018/PTUN MTR, dengan keputusan panitia pemilihan Kepala Desa Masbagik Selatan, Kecamatan Masbagik Kabupaten Lombok Timur-NTB tentang penetapan Calon Kepala Desa Terpilih Nomor 023/PPKD-MASSEL/XII/2017 tanggal 15 Desember 2017.

Panitia Pemilihan Kepala Desa Masbagaik Selatan bertindak untuk mejaga kehati-hatian dan menjaga suasana kondusif pada tanggal 13 Desember 2017 panitia belum mengambil keputusan atau menetapkan siapa Calon Kepala Desa yang terpilih, melainkan panitia mencoba melakukan koordinasi lebih lanjut ke BPD, Camat Masbagik dan DPMD, tepatnya pada tanggal 14 Desember 2017 dalam koordinasi yang dilakukan oleh panitia dengan BPD, Camat Masbagik, Pengawas Kecamatan, DPMD dan Kepolisian untuk merumuskan Calon Kepala Desa Terpilih mengacu pada Peraturan Bupati Kabupaten Lombok Timur No 15 Tahun 2016 Tentang Peraturan Pelaksana Peraturan Daerah Nomor 4 Tahun 2015 Tentang tatacara Pengangkatan dan Pemberhentian Kepala Desa yaitu pasal 56 ayat (1) yakni "Dalam hal Terdapat Calon Kepala desa yang
Memperoleh suara terbanyak yang sama, penetapan Calon Kepala Desa Terpilih berdasarkan wilayah perolehan suara yang lebih luas yang di perhitungkan berdasarkan jumlah perolehan suara terbanyak dan sebaran TPS yang lebih banyak", maka berdasarkan hasil rekapitulasi yang ada dapat diperoleh sebaran suara yang diperoleh oleh calon kepala desa nomor urut 4 dan Calon kepala desa nomur urut 5, yaitu sebagai berikut:

Tabel 2: Sebaran Kemenangan Calon

\begin{tabular}{|l|c|}
\hline \multicolumn{1}{|c|}{ NAMA } & SEBARAN SUARA \\
\hline 1. H.Wiriyawan, SH & 14 TPS \\
\hline 2. Masdar & 10 TPS \\
\hline
\end{tabular}

Berdasarkan aturan dan daftar sebaran yang di peroleh panitia, Calon Nomor Urut 4 yaitu Wiriyawan, $\mathrm{SH}$ memperoleh sebaran terbanyak dan dapat ditetapkan sebagai Kepala desa Terpilih, kemudian membacakan hasil penetapan panitia kepada seluruh calon Kepala Desa. Panitia Pemilihan Kepala Desa, apa yang Tegugat lakukan sudah berdasarkan pada peraturan perundangundangan yang berlaku. hal ini dapat dilihat dari hasil pemeriksaan badan penyelesain sengketa yang tertuang dalam Keputusan Bupati Nomor: 14/39/BPMD/2018 tentang Jawaban Sengketa Pilkades Masbagik Selatan, tanggal 17 Januari 2018 yang menyatakan sebagai berikut :

a. Pengajuan keberatan saudara sampaikan masih dalam tenggang watu sesuai Peraturan Bupati Nomor 15 Tahun 2016, tentang Peraturan Pelaksana Peraturan Daerah Nomor 4 Tahun 2015 ayat (1);

b. Tahapan keberatan Saudara Pada Poin 2 di temukan fakta bahwa TPS 25 belum Masuk dalam penjumlahan secara menyeluruh jumlah perolehan suara sama; dan

c. Tahapan jumlah suara yang sama maka pemenang mengacu kepada ketentuan pasal 56 ayat (1) dalam Peraturan Bupati Nomor 15 tahun 2016,Tentang Perturan Pelaksana peraturan Daerah Nomor 4 tahun 2015, dalam hal terdapat calon kepala desa yang memeperoleh suara terbanyak sama, penetapan calon 
kepala desa terpilih berdasarkan wilayah perolehan suara yang lebih luas yang di perhitungkan berdasarkan jumlah perolehan suara terbanyak dan sebaran TPS yang lebih banyak.

d. Berdasrkan poin 1, 2, dan 3 diatas maka dengan ini di sampaikan bahwa keberatan saudara tidak dapat di penuhi;

Panitia Pemilihan Kepala Desa, dengan menggutip Surat Keputusan Bupati Nomor 14/39/PMD/2018 tentang Jawaban Sengketa Pilkades Desa Masbagik Selatan terhadap keberatan atas hasil Pilkades Masbagik Selatan yang di lakukan oleh calon kepala desa Nomor urut 5 nama Masdar sudah di putuskan oleh Kabupaten Lombok Timur dan sesuai dengan Perturan Bupati Nomor 15 Tahun 2016, Tentang Peraturan pelaksana peraturan Daerah Nomor 4 Tahun 2015, Pasal 58 ayat (6) yang berbunyi "Keputusan Bupati Sebagaimana dimaksud Pada ayat (4) bersifat final dan Mengikat".

Panitia Pemilihan Kepala Desa juga membatah dalil Masdar yang menyatakan Panitia Pemilihan Kepala Desa telah melakukan pelanggaran dimana dalam jawaban Panitia Pemilihan Kepala Desa atas gugatan Masdar di PTUN menyatakan "...mulai tahapan Pemungutan Suara dan penghitungan suara di 24 TPS yang ada, tidak terdapat kecurangan atau sengketa, hal ini terlihat dari semua saksi tidak mengisi Form Keberatan, dan telah menandatangani berita hasil penghitungan suara (Form C1) ditingkat TPS. Kemudian ditingkat penghitungan komulatif walupun terdapat sedikit kekeliruan awal dalam penjumlahan, namun setelah dilakukan penghitungan secara berulang-ulang dan disaksikan oleh saksi dari calon kepala desa, BPD, Babinsa, Polmas, Perwakilan Kecamatan Masbagik, Tokoh Masyarakat, dan simpatisan dari para calon kepada desa yang di lakukan di Kantor Desa juga tidak di temukan keberatan terhadap perolehan hasil penghitungan komulatif tersebut, dimana di peroleh dari penghitungan komulatif terhadap dua pasangan calaon kepala desa yang memperoleh suara sama (draw) yaitu calon kepala desa nomor urut 4 dan calon kepala desa nomor urut 5 , serta sebelum menentukan kepala desa terpilih, panitia juga telah melibatkan BPD, Camat Masbagik, dan DPMD untuk merumuskan Calon Kepala Desa terpilih".

Dalam pembuktian sengketa administrasi di PTUN Mataram terungkap selain keberatan atas hasil perhitungan suara, Masdar selaku Penggugat mengajukan 2 (dua) kali permohonan perhitungan suara ulang sebelum penetapan calon terpilih yaitu surat bukti yang diberi tanda P-3: Surat Mohon Penghitungan Ulang Tanggal 25 Rabiul Awal 1439 H/14 Desember 2017 dari Calon Nomor 5 atas nama MASDAR kepada Bupati Lombok Timur dan bukri P-4 : Surat : Lepas, Lamp. : Mohon Penghitungan Ulang tanggal 27 Rabiul Awal 1439 H/16 Desember 2017 dari Calon Nomor 5 atas Nama Masdar Kepada Panitia Pemilihan Kepala Desa Masbagik Selatan.

Permohonan tersebut tidak ada tanggapan sama sekali dari Panitia Pemilihan Kepala Desa Masbagik Selatan, bahkan Badan Permusyawaratan Desa, telah menyampaikan laporan hasil pemilihan Kepala Desa Masbagik dengan Surat Nomor 003/BPD.MASSELXII/2017, Perihal: Laporan panitia Badan Permusyawaratan Desa (BPD) Kepada Bupati Lombok Timur melalui Camat Masbagik, tanggal 18 Desember 2017 dan Keputusan Badan Permusyawaratan Desa (BPD) Desa Masbagik Selatan Nomor 01/BPD.Massel/VIII/2107, Tanggal 25 Agustus 2017.

Sebagaimana yang telah diuraikan diatas, dimana dalam kenyataannya tidak adanya aturan yang tegas dalam peraturan perundangan-undangan dari tingkat pusat sampai aturan pelaksanaan di tingkat daerah yang secara tegas mengatur mekanisme dan prosedur proses penyelesaian sengketa Pilkades ditingkat desa yang dibentuk oleh BPD maupun Panitia Pilkades Tingkat Kabupaten yang dibentuk Bupati, tidak mampu memberikan solusi atas permasalahan baik yang terkait dengan proses maupun hasil. Bahkan Panitia Pemilihan Kepala Desa Tingkat Kabupaten hanya memberikan jawaban atas permohonan sengketa tanpa memeriksa pengaduan yang disampaikan oleh penggadu dalam hal ini adalah Masdar. Seharusnya proses ajudikasi dilakukan untuk memeriksa permohonan Masdar atas keberatannya sebagaimana asas hukum Audi et Alteram Partem yang artinya "Mendengarkan dua 
belah pihak" atau mendengarkan juga pendapat atau argumentasi pihak yang lainnya sebelum menjatuhkan keputusan, hal ini sebagai salah satu cara pengambilan keputusan pihak yang berwenang setelah memberikan kesempatan kepada para pihak menyampaikan argumentasi dan bukti-bukti sebagai alat pendukungnya, sebagaimana menjadi asas hukum tertinggi dalam sengketa administrasi.

\section{2) Pertimbangan Hukum Putusan Pengadilan Tata Usaha Negara}

Majelis hakim Pengadilan Tata Usaha Negara Mataram yang memeriksa, mengadili dan memutus sengketa Pilkades Desa Masbagik Selatan dalam pertimbangan hukumnya sebagaimana terurai dibawah ini.

Berdasarkan Pasal 58 Ayat (1) Peraturan Bupati Lombok Timur Nomor 15 Tahun 2016 Tentang Peraturan Pelaksanaan Daerah Nomor 4 Tahun 2015 Tentang Tata Cara Pemilihan Dan Pemberhentian Kepala Desa dinyatakan sebagai berikut Ayat (1): kebertan terhadap penetapan hasil Pemilihan Kepala Desa hanya dapat diajukan oleh Kepala Desa kepada Bupati dalam waktu paling lambat tiga hari setelah penetapan hasil pemilihan. Bahwa terlepas dari kewenangan Bupati untuk menyelesaiakan keberatan terhadap hasil penghitungan suara, tidak terdapat Peraturan sebagai dasar adanya pengajuan banding Administratif terhadap penyelesain perselisiahan hasil penghitungan suara selain Peraturan Dasar mengenai upaya administratif berupa pengajuan surat keberatan (tertulis).

Upaya hukum yang dapat ditempuh atas ketidakpuasan terhadap hasil penyelesain keberatan tersebut adalah dapat diajukan gugatan kepengadilan Tata Usaha Negara sebagai pengadilan tingkat pertama, dengan diajukan Keputusan Panitia Pemilihan Kepala Desa Masbagik Selatan, Kecamatan Masbagik, Kabupaten Lombok Timur Nomor 023/PPKD-MASSEL/XII/2017， tanggal 15 Desember 2017 tentang Penetapan Calon Kepala Desa Terpilih Desa Masbagik Selatan, Kecamatan Masbagik, Kabupaten Lombok Timur Periode 2017 s/d 2023 sebagai objek sengketa, maka menurut Majelis Hakim bukan merupakan objek banding administratif yang merupakan kewenangan pengadilan tinggi Tata Usaha Negara
Surabaya, namun merupakan kewengangan pengadilan Tata Usaha Negara Mataram untuk memeriksa, memutus, dan menyelesaikan sengketa tersebut.

Eksepsi Tergugat terkait Pengadilan Tinggi Tata Usaha Negara Surabaya yang berwenang megadili sengketa a quo adalah tidak beralasan Hukum. Sedangkan terhadap eksepsi Tergugat dan Tergugat II Intervensi sepenuhnya menurut Majelis Hakim adalah terkait ketentuan formal dari objek sengketa Tata Usaha Negara. Bahwa bersifat final menurut Pasal 1 adalah sudah divinitif dan menimbulakan akibat hukum, apabila dihubungkan dengan objek sengketa, menurut Majelis Hakim PTUN Mataram objek sengketa menimbukan akibat hukum ditetapkanya Calon Kepala desa Terpilih Menurut Pasal 87 Undang-Undang Nomor 30 Tahun 2014 Keputusan berpotensi menimbulkan akibat hukum dapat digugat di Pengadilan Tata Usaha Negara, dengan tidak dicantumkanya Keputusan Bupati Lombok Timur sebagi tindak lanjut Objek sengketa, menurut majelis hakim tidak mengurangi Unsur Formal gugatan. Sehingga eksepsieksepsi Tergugat dan Tergugat II Intervensi terkait objek sengketa bukan termasuk Keputusan Tata Usaha Negara karena belum bersifat final serta gugatan seharusnya maencantumkan Keputusan Bupati Lombok Timur Nomor 188.45/88/PMD/2018 adalah tidak beralasan hukum.

Selanjutnya pertimbangan majelis hakim PTUN Mataram dalam pokok perkara atas dalil-dalil gugatannya pada pokoknya menyatakan tindakan Tergugat bertentangan dengan asas kepastian hukum, asas keterbukaan dan asas keadilan dan kewajaran serta asas kepentingan Umum. Penggugat mendalilkan terbitnya objek sengketa oleh Tergugat telah menimbulkan kerugian kepada Penggugat dimana pada penghitungan tahap pertama Penggugat telah dinyatakan menang dengan selisih 29 suara dari Tergugat II Intervensi dinyatakan sama (Draw) dan dari hasil pengumuman yang dinyatakan draw tersebut Tergugat menetapakan objek sengketa, atas sikap Tergugat tersebut Penggugat mengajukan Keberatan kepada Bupati Lombok Timur dengan Tuntutan supaya dilakukan penghitungan ulang. Sedangkan Tergugat mendalilkan ketika menjumlahkan perolehan 
suara dengan selisih 29 suara antara Penggugat dan Tergugat II Intervensi, Tergugat memutuskan dan menetapkan siapa pemenang Calon Kepala Desa Terpilih terdapat perbadaan total suara yaitu 7980 dengan Total suara sah 8115, kemudian Tergugat mengajak kepada semua Saksi, Simpatisan, Tokoh Masyarakat, Babinsa, BPD, Polmas, dari pihak kecamatan yang hadir untuk menghitung kembali bersama dan secara berulang akhirnya diperoleh suara yaitu Penggugat dan Tergugat II Intervensi Draw, dan bedasarkan pasal 56 ayat (1) Perturan Bupati Lombok Timur Nomor 15 Tahun 2016 tentang Peraturan Pelaksana Peraturan Daerah Nomor 4 tahun 2015 tentang Tata cara Pemilihan dan Pemberhentian Kepala Desa, maka Tergugat II Intervensi di tetapkan sebagia Calon Kepala Desa Terpilih.

Fakta hukum menunjukkan Penggugat telah keliru karena menyakini catatan daftar rekapitulasi yang belum selesai (vide surat dalam bukti P-1) dengan jumlah yang keliru, baik terhadap perolehan suara Penggugat sendiri karena mengabaikan 47 suara pemilihan maupun jumlah perolehan suara Tergugat maupun jumlah perolehan suara Tergugat II Intervensi dan Tergugat serta terdapat jumlah suara yang keliru dan dicoret dan diperbaiki sebagaimana dalam bukti T-8.

Perbaikan terhadap pengitungan surat suara menurut Majelis Hakim adalah justeru untuk mewujudkan kepastian Hukum, hal demikian merupakan bagian dari kewajiban Tergugat untuk menggendalilkan semua tahapan pelaksanaan pemilihan sebagaimana ketentuan. Kemudian, mencermati Pleno, vide surat dalam bukti tercatat jumlah yang sama dalam surat dalam bukti T-8 maupun rekapitulasi hasil; perolehan suara (vide Surat dalam bukti T-3), dengan demikian objek sengketa bahwa subtansinya sesuai dengan hasil perolehan suara calon Pemilihan Kepala Desa Masbagik Selatan.

Surat dalam bukti T-8 tidak mencatat siapa yang jadi pemenang namun mencatatkan jumlah perolehan suara yang Draw antara Penggugat dan Tergugat II Intervensi maksud Penggugat untuk menunda penetapan in casu objek sengketa justru menimbulkan ketidakpastian hukum. Selanjutnya Penetapan in casu Objek sengketa tersebut dapat diajukan keberatan oleh Penggugat kepada Bupati Lombok Timur, Karena telah menentukan siapa yang menjadi Calon Kepala Desa Terpilih. Fakta hukum menunjukan Penggugat telah keliru karena catatan daftar rekapitulasi yang belum selesai (vide Surat dalam bukti P-1 dengan jumlah yang keliru), perolehan suara Penggugat sendiri karena mengabaikan 40 suara pemilih penggugat maupun jumlah Tergugat II Intervensi.

Bahwa dengan demikian penertiban objek sengketa menurut majelis hakim telah sesuai dengan peraturan yang berlaku, khususnya Peraturan Bupati Lombok Timur Nomor 15 tahun 2016 tentang Peraturan Daerah Nomor 4 tahun 2015 tentang Tatacara Pemilihan dan Pemberhentian Kepala Desa.

Berdasarkan uraian pertimbangan hukum tersebut maka dalil Penggugat yang menyatakan tindakan Tergugat bertentangan dengan asas keterbukaan, asas keadilan, dan kewajaran serta asas kepentingan umum dinyatakan tidak berlaskan hukum. Berdasarkan seluruh rangkaian pertimbanagan hukum tersebut diatas, majelis hakim berkesimpulan bahwa tindakan Tergugat dalam menerbitkan objek sengketa a quo telah sesuai dengan peraturan perundang-undangan yang berlaku dan asasasas umum pemerintahan yang baik.

Dengan demikian terhadap tuntutan Penggugat agar objek sengketa a quo dinyatakan batal atau tidak sah dan mewajibkan Tergugat untuk mencabut objek sengketa a quo dan mengeluarkan putusan Tata Usaha Negara yang baru atas nama Penggugat adalah tidak beralasan hukum dan patut untuk ditolak dan terhadap Pengggugat patut dinyatakan di tolak seluruhnya.

Majelis hakim perkara Pengadilan Tata Usaha Negara Mataram Nomor 08/2018/PTUN.MTR, menjatuhkan putusan sebagai berikut:

a. Dalam penundaan

Menolak permohonan penundaan pelaksanaan surat keputusan obyek sengketa yang dimohonkan Penggugat;

b. Dalam Pokok Perkara

Menolak gugatan Penggugat untuk seluruhnya dan Menghukum penggugat membayar biaya perkara 
sebesar Rp. 393.000.00 (tiga ratus

Sembilan puluh tiga ribu rupiah)

Pihak Masdar yang dikalahkan dalam perkara tersebut mengajukan banding ke Pengadilan Tinggi Tata Usaha Negara Surabaya pada pokoknya pertimbangan majelis hakim tinggi adalah menguatkan Putusan Pengadilan Tata Usaha Negara Mataram Nomor 08/2018/PTUN.MTR, tanggal 30 Mei 2018 yang dimohonkan banding menghukum pembanding /Penggugat membayar biaya perkara pada dua peradilan yang dalam tingkat banding ditetapkan sebesar 250.000-(Dua Ratus Lima Puluh Ribu Rupiah).

\section{3) Penyelesaian Sengketa Pemilihan Kepala Desa Pelanggaran Proses Pelaksanaan Tidak Operasional.}

Sengketa Hasil Pemilihan Kepala Desa Masbagik Selatan Kecamatan Masbagik terjadi akibat adannya keberatan dari Calon Kepala Desa Masbagik Selatan Nomor urut 5 (lima) atas nama Masdar Kecamatan Masbagik, Kabupaten Lombok Timur, berdasarkan surat yang dialamatkan ke Bupati Lombok Timur, Nomor Lepas, Perihal Mohon Penghitungan Ulang, tanggal 14 Desember 2017, dimana hasil perhitungan.

Sehubungan dengan Hasil Penghitungan Pemilihan Kepala Masbagik Selatan Pada hari Rabu, 13 Dasember 2017 yang menyatakan bahwa saya atas nama Masdar Calon Urut 5 dinyatakan sebagai pemenang dalam Pemilihan Kepala Desa Masbagik Selatan disaksikan oleh para saksi, pihak keamanan (Polri dan TNI), ormas, para pendukung dan khalayak dengan selisih Kemenangan 29 suara dari calon Nomor 4 atas nama $\mathrm{H}$. Wiriyawan, SH dan hal itu dikatakan Final oleh Panitia. Adapaun Prosesnya sebagai berikut :

1) Penghitungan I

Tabel 3: Penghitungan dilakukan panitia dihadiri saksi-saksi dan pihak keamanan (Kepolisian dan TNI) serta pendukung.

\begin{tabular}{|c|c|c|}
\hline No. & $\begin{array}{c}\text { Calon } \\
\text { Nomor }\end{array}$ & Jumlah Perolehan Suara \\
\hline 1 & 1 & 551 \\
\hline 2 & 2 & 1573 \\
\hline 3 & 3 & 1097 \\
\hline 4 & 4 & 2365 \\
\hline 5 & 5 & 2394 \\
\hline \multicolumn{2}{|c|}{ Jumlah } & $\mathbf{7 9 8 0}$ \\
\hline
\end{tabular}

Setelah pengumuman Hasil penghitungan pada pendukung secara sepontan pulang dan beredar kemenangan atas nama saya yaitu Masdar (Calon Nomor 5).

2) Penghitungan II

Setelah perhitungan pertama kemudian dilakukan perhitungan ke -2 dihari yang sama, Panitia menganggap hasil penghitungannya keliru dan mengeluarkan hasil penghitungan terbaru dengan rincian sebagai berikut:

Tabel 4: Penghitungan dilakukan Panitia dihadiri saksi-saksi dan pihak keamanan (Kepolisian dan TNI) dan sebagian para pendukung.

\begin{tabular}{|c|c|c|}
\hline $\begin{array}{c}\text { Nomor } \\
\text { Urut }\end{array}$ & $\begin{array}{c}\text { Calon } \\
\text { Nomor }\end{array}$ & $\begin{array}{c}\text { Jumlah Perolehan } \\
\text { Suara }\end{array}$ \\
\hline 1 & 1 & 551 \\
\hline 2 & 3 & 1573 \\
\hline 3 & 3 & 1109 \\
\hline 4 & 4 & 2441 \\
\hline 5 & 5 & 2441 \\
\hline \multicolumn{2}{|c|}{ Jumlah } & $\mathbf{8 1 1 5}$ \\
\hline
\end{tabular}

Sehubungan dengan hal tersebut, Masdar sangat berkebaratan terlebih pendukung dengan alasan sebagai berikut :

1) Adannya kejanggalan jumlah antara penghitungan tahap I dan tahap II pada penghitungan tahap I berjumlah 7980 suara dan pada penghiutngan tahap II berjumlah 8115 suara. Artinya terjadi 135 suara setelah adanya jeda penghitungan. Saya mempertanyakan proses dan prosedur yang dilakukan setelah jeda waktu.

2) Adannya kejanggalan dengan alasan yang menganggap system computer yang eror dalam system penjumlahan. Seharusnya ketika kolom dan set pada 1 kotak, maka perubahannya jumlahnya akan diikuti kolom dan set kotak berikutnya. Hal ini menyebabkan tidak signifikannya perubahan jumlah suara masing-masing calon.

Alasan keberatan Masdar (calon nomor urut 5) tidak menerima hasil draw dan dengan rendah hati kami memohon agar surat suara di dalam kotak suara dihitung ulang secara keseluruhan demi menjamin 
proses transparansi untuk keamanan dan kenyamanan masyarakat umum.

DPMPD melakukan musyawarah unntuk menyelesaikan sengketa tersebut, musyawarah dihadir oleh BPD, PPS yang terkait, KPPS yang terkait, Panitia Pengawas Kecamatan, Panitia Kabupaten dan Tim Penyelesaian Sengketa Hasil Penghitungan suara yang dibentuk langsung oleh Bupati Lombok Timur, setelah melakukan Musyawarah Tim penyelesaian sengketa Pemilihan Kepala Desa mengambil kesimpulan

1) Pengajuan kebaratan saudara sampaikan masih dalam tenggang waktu sesuai dengan Peraturan Daerah Nomor 4 Tahun 2015, pasal 58 ayat (1);

2) Terhadap keberatan Saudara pada pion 2 ditemukan fakta bahwa pada TPS 25 belum Masuk Dalam penjumlahan secara keseluruhan dan setelah dilakukan penjumlahan secara menyeluruh jumlah perolehan suara sama;

3) Tahap jumlah suara yang sama maka pemenang mengacu pada ketentuan pasal 56 ayat (1) dalam hal Terdapat Calon Kepala Desa yang memperoleh suara sama, maka pemenang dari penetapan calon kepala desa terpilih berrdasarkan wilayah perolehan suara yang lebih luas. yang diperhitungkan berdasarkan sebaran wilayah perolehan saura TPS yang lebih banyak";

4) Berdasrkan point 1,2 dan 3 diatas maka dengan ini disampaikan bahwa kebratan Saudara dinyatakan tidak dapat dipenuhi.

Dari kesimpulan diatas Tim Penyelesaian Sengketa Pemilihan Kepala Desa merekomendasikan Kepala Desa terpilih kepada Bupati Lombok Timur untuk ditetapkan menjadi Kepala Desa Masbagik Selatan. Dari apa yang tertuang dalam Peraturan Bupati Lombok Timur Nomor 15 Tahun 2016 tentang peraturan pelaksanaan peraturan daerah Nomor 4 Tahun 2015 Tentang Tata Cara Pemilihan Dan Pemberhentian Kepala Desa dan apa yang telah dilaksanakan oleh pemerintah daerah untuk penyelesaian sengketa Pilkades dapat dijelaskan pola penyelesaiannya.

Ketentuan mengenai mekanisme penyelesaian sengketa Keberatan hasil penghitungan suara pemilihan Kepala Desa secara jelas tertuang dalam Pasal 58 Perda Nomor 4 tahun 2015, serta di dalam pasal 59 menyatakan yaitu : bahwa apabila setelah penyelesaian perselisihan dalam jangka waktu sebagai mana dimaksud dalam Pasal 58 ayat 5 (lima) masih terdapat pengajuan keberatan atas penetapan Calon Kepala Desa Terpilih, maka pelantikan calon Kepala Desa Terpilih Tetap dilaksanakan.

Melihat ketentuan di atas bahwa diketahui pola penyelesaian sengketa yang dilaksanakan oleh Bupati Lombok Timur dengan Memperhatikan masukan dari Panitia Pemilihan Kepala Desa, BPD, Camat, dan Tim yang dibentuk oleh Bupati. Dan apabila setelah penyelesaian sengketa yang dilakukan oleh Bupati Lombok Timur, masih terdapat pengajauan keberatan atas penetapan calon Kepala desa terpilih maka pelantikan calon kepala Desa Terpilih tetap dilaksanakan.

Berdasarkan uraian diatas penyelesaian permasalahan Pilkades di tingkat kabupaten, bisa dilakukan oleh panitia pemilihan kepala desa tingkat kabupaten, sebagaimana diatur dalam Pasal 5 ayat (2) huruf $f$ Permendagri Nomor 112 Tahun 2014 yang diatur ulang dalam Pasal 6 ayat (2) huruf $f$ Peraturan Daerah Kabupaten Lombok Timur Nomor 4 Tahun 2015. Namun demikian, ketentuan tersebut masih memberikan dasar kewenangan yang dapat dilakukan oleh panitia pemilihan kepala desa tingkat Kabupaten Lombok Timur, tetapi mekanisme dan tata cara penyelesaiannya seharusnya perlu ada pengaturan lanjutan, jika tidak, sama saja akan menemui ketidakjelasan dalam penyelesaian permasalahan terkait dengan proses pemilihan kepala desa.

Dilihat kemudian dari Peraturan Bupati Nomor 15 tahun 2016 pasal 58 ayat (4) yakni "Bupati memutus sengketa hasil perhitungan suara dengan memperhatikan masukan dari panitia pemilihan kepala desa, BPD, camat dan tim yang dibentuk Bupati". Secara tegas tidak ditemukan adanya kewenangan Panitia Tingkat kabupaten untuk menyelesaikan sengketa yang ada berdasarkan pemgaduan yang ada. Sehingga aturan teknis dan 
prosedur dalam penyelesaian sengketa Pilkades yang tidak terang dan jelas ini tidak menjadi pertimbangan majelis hakim PTUN Mataram untuk menguji keberatan Masdar atas dasar apa perhitungan suara dilakukan Ketika perhitungan suara sudah dilakukan kemudian dilakukan ulang sebagaimana pengakuan Panitia Pemilihan Desa Masbagik Selatan atas jawaban gugatan Penggugat dalam sengketa PTUN Mataram.

\section{KESIMPULAN}

Prosedur dan mekanisme yang dilakukan oleh Bupati Lombok Timur dalam penyelesaian sengketa atas Pemilihan Kepala Desa yaitu dengan Memperhatikan masukan dari Panitia Pemilihan Kepala Desa, BPD, Camat, dan Tim yang dibentuk oleh Bupati. Dan apabila setelah penyelesaian sengketa yang dilakukan oleh Bupati Lombok Timur, masih terdapat pengajauan keberatan atas penetapan calon Kepala desa terpilih maka pelantikan calon kepala Desa Terpilih tetap dilaksanakan. Hal ini menunjulkan tidak jelasnya mekanisme penyelesaian sengketa yang dilakukan pada tingkat kabupaten yang tidak dipertimbangkan oleh Majelis Hakim PTUN Mataram atas keberatan yang diajukan oleh Masdar.

Pertimbangan hukum majelis hakim PTUN Mataram dalam menjatuhkan putusan kurang memperhatikan fakta-fakta yang terungkap, mengapa ada perhitungan suara ulang dan apakah berita acara Form $\mathrm{C} 1$ yang saksi tandatangani juga berkaitan dengan perhitungan ulang, karena ada 2 (dua) kali keberatan permohonan perhitungan ulang yang dilakukan oleh Masdar.

Permasalahan Pilkades di tingkat kabupaten, bisa dilakukan oleh panitia pemilihan kepala desa tingkat kabupaten, sebagaimana diatur dalam Pasal 5 ayat (2) huruf f Permendagri Nomor 112 Tahun 2014 yang diatur ulang dalam Pasal 6 ayat (2) huruf $f$ Peraturan Daerah Kabupaten Lombok Timur Nomor 4 Tahun 2015. Tetapi secara aturan teknis yakni Peraturan Bupati Nomor 15 tahun 2016 pasal 58 ayat (4) hanya sebatas aturan dengan mempertimbangkan saran dan pendapat panitia yang dibentuk oleh Bupati dalam memutus perkara sedangkan faktanya pemeriksaan kepada pihak yang mengajukan keberatan tidak pernah dilakukan.
Pengaturan pemilihan kepala desa di tingkat Kabupaten sebagai tindak lanjut dari Undang-Undang tentang Desa dan peraturan pelaksanaannya berisi tentang kewajiban panitia pemilihan menyampaikan penetapan hasil perolehan suara yang menetapkan calon terpilih kepada calon (para calon) kepala desa, selain kepada BPD, mekanisme dan prosedur pengajuan keberatan sesuai batas waktu yang ditentukan, kewajiban bupati/walikota atau tim yang dibentuk untuk mempertemukan para pihak yang berselisih, dan jika tidak terjadi kesepakatan, maka bupati/ walikota bersama tim yang dibentuk wajib menyelesaikan perselisihan hasil. Aturan-aturan teknis ini penting dibuatkan segera oleh pemerintah kabupaten Lombok Timur;

Mahkamah Agung perlu membuat pedoman teknis penyelesaian sengekta pemilihan kepala desa, agar ada panduan bagi hakim-hakim tingkat pertama untuk menyelesaikan perkara Pilkades sebagaimana perkara Pilkada yang sudah diatur dalam Perma.

\section{DAFTAR PUSTAKA}

\section{Buku}

A.D. Belinfate \& Boerhanuddin Soetan Batoeah, Pokok-pokok Tata Usaha Negara, (Bina Cipta: Jakarta, 2007).

Bahdin Nur Tnjung dan Ardial,Pedoman Penulisan Karya Tulis IImiah (Jakarta: Jakarta Kencana Prenada Media Group,2010).

Bambang Waluyo,.Penelitian Hukum dan praktek, Catatan Ketiga, (Sinar Grafika: Jakarta, 2002)

Bambang Sutuiyoso, Metode Metode Penemuan Hukum, (UIIPres, yogyakarta: 2006).

Dwipayana AAGN Ari etl, Membangun Good Governanance di desa, (Yogyakarta: IRE Press, 2003).

E Utrec dalam Ridwan HR, Hukum Administarasi Negara, Cet. VI (Raja Gravindo Persada: Jakarta,2007).

Nasition,S., Metode Penelitian Kualitatif, (Tarsito: Bandung,1992),

Peter Mahmud Marzuki,Penelitian Hukum Prenada Media Group.Jakarta 2008. 
Penelitian Hukum, (Kencana Prenada Media Group: Jakarta, 2011).

S. F. Marbun \& Moh. Mahfud MD, PokokPokok Hukum Administrasi Negara, Cet. V, (Liberty: Yogyakarta, 2009).

SF. Marbun, Peradilan Administrasi Negara dan Upaya Administratif di Indonesia, Cet.III, (FH UII Press: yogyakarta, 2011).

Saparin, Tata Pemerintah dan Administrasi Desa, (Jakarta:Ghalia, 1998).

Sima Rista, Demokrasi Akar Rumput Damai, konpetitif, Mendidik, Majalah Gempita Gumi Selaparang, Edisi Oktober 2016.

Sukarna, Kapita Selekta Administrasi Negara, (Alumni: Bandung, 1986).

Sudikno Mertokusumo, Penemuan Hukum Sebuah Pengantar, (Liberty, Yogyakart:1998).

\section{Peraturan Perundang-undangan}

BPMPD Kab. Lotim, "Rekapitulasi Data Pemilihan Kepala Desa Serentak'di Kab. Lombok Timur Tahun 2016.

Pasal 37 Ayat (5)Undang -Undang Nomor 6 Tahun 2014 tentang Desa (Lembaran NegaraTahun 2014 Nomor 7, Tambahan Lembaran Negara Nomor 5495).

Undang-Undang Nomor 23 Tahun 2014 tentang Pemerintahan Daerah;

Undang-Undang No. 2 Tahun 2015 tentang Penetapan Peraturan Pemerintah Pengganti Undang-Undang Nomor 2 Tahun 2014 tentang Perubahan atas Undang-Undang Nomor 23 Tahun 2014 tentang Pemerintahan Daerah Menjadi Undang-Undang;

Undang-Undang No. 9 Tahun 2015 tentang Perubahan Kedua Undang-Undang Nomor 23 Tahun 2014 tentang Pemerintahan Daerah;

Undang-Undang No. 6 Tahun 2014 Tentang Desa;

Peraturan Pemerintah Republik Indonesia Nomor 43 tahun 2014 Tentang Peraturan Pelaksanaan UndangUundang Nomor 6 Tahun 2014 Tentang Desa;

Peraturan Pemerintah Republik Indonesia Nomor 47 tahun 2015 Tentang Perubahan Atas Peraturan Pemerintah Republik Indonesia Nomor 43 tahun
2014 Tentang Peraturan

Pelaksanaan Undang-Uundang Nomor 6 Tahun 2014 Tentang Desa;

Peraturan Menteri Dalam Negeri No. 112 Tahun 2014 tentang Pemilihan Kepala Desa;

Peraturan Daerah Kabupaten Lombok Timur Nomor 4 Tahun 2015 Tentang Tata Cara Pemilihan dan Pemberhentian Kepala Desa;

Peraturan Bupati Kabupaten Lombok Timur Nomor 15 Tahun 2015 tentang Peraturan Pelaksana Peraturan Daerah Kabupaten Lombok Timur Nomor 4 Tahun 2015 Tentang Tata Cara Pemilihan dan Pemberhentian Kepala Desa

\section{Internet}

Basri Mulyani, Zainul Fikri, 2015, Perilaku Memilih: Analisis Terhadap Tingginya. Surat Suara Tidak Sah (Studi Kasus Kota Mataram, Laporan Hasil Penelitian (Online) http:/,repository.g.ac,id:1015/id/eperi nt/18, (diakses tanggal 9 Februari 2020) 